\title{
Patients' knowledge of Diabetes five years after the end of an educational program
}

\author{
CONHECIMENTO DE PACIENTES COM DIABETES SOBRE TRATAMENTO APÓS CINCO ANOS \\ DO TÉRMINO DE UM PROGRAMA EDUCATIVO
}

\section{CONOCIMIENTO DE PACIENTES CON DIABETES SOBRE EL TRATAMIENTO DESPUÉS DE CINCO AÑOS DE CULMINADO UN PROGRAMA EDUCATIVO}

\author{
Izabel Alves das Chagas ${ }^{1}$, Josana Camilo², Manoel Antônio dos Santos ${ }^{3}$, Flávia Fernanda \\ Luchetti Rodrigues ${ }^{4}$, Clarissa Cordeiro Alves Arrelias ${ }^{5}$, Carla Regina de Souza Teixeira ${ }^{6}$, \\ Liudmila Miyar Otero ${ }^{7}$, Maria Lúcia Zanetti ${ }^{8}$
}

\begin{abstract}
We present a cross-sectional study that aims to describe the sociodemographic and clinical conditions of individuals with diabetes mellitus and to analyze their knowledge of treatment five years after the end of an educational program in which they took part. In 2010, 40 individuals who had participated in a diabetes educational program for 12 months in 2005 at a primary care service were interviewed. A form was used for data collection that included their knowledge of the notion, physiopathology, and treatment of the disease; exercise; nutrition; foot care; self-monitoring of capillary blood glucose at home; hypoglycemia; chronic complications; special situations; and family support. The results showed that the volunteers incorporated the information about the notion, physiopathology, and treatment of the disease; exercise; foot care; self-monitoring; care associated with hypoglycemia; chronic complications; and special situations. In contrast, nutrition and family support require further reinforcement. It is concluded that five years after the end of the educational program, the participants kept most of the information provided.
\end{abstract}

\section{RESUMO}

Estudo transversal que teve como objetivos descrever as características sociodemográficas e clínicas e analisar o conhecimento de pacientes com diabetes mellitus sobre o tratamento após cinco anos do término de um programa educativo. Foram entrevistados, em 2010, 40 pacientes que, em 2005, haviam participado de programa de educação em diabetes, oferecido por um período de 12 meses, em um serviço de atenção primária. Utilizou-se formulário contendo: conceito, fisiopatologia e tratamento da doença, exercício físico, alimentação, cuidados com os pés, automonitorização da glicemia capilar no domicílio, hipoglicemia, complicações crônicas, situações especiais e apoio familiar. Os resultados mostraram que foram incorporados conhecimentos em relação a conceito, fisiopatologia e tratamento da doença, atividade física, cuidado com os pés, automonitorização, cuidados com hipoglicemia, complicações crônicas e situações especiais. Por outro lado, alimentação e apoio familiar necessitam de maior incremento. Concluiuse que, decorridos cinco anos do processo educativo, houve retenção da maior parte dos conhecimentos ministrados.

\section{RESUMEN}

Estudio transversal que tuvo como objetivos: describir las características socio-demográficas y clínicas, y analizar el conocimiento de pacientes con diabetes mellitus acerca del tratamiento después de cinco años de culminado un programa educativo. En el 2010, fueron entrevistados 40 pacientes que habían participado en el 2005, de un programa de educación en diabetes, ofrecido por un período de 12 meses, en un servicio de atención primaria. Se utilizó un formulario que contenía: concepto, fisiopatología y tratamiento de la enfermedad, ejercicio físico, alimentación, cuidados con los pies, automonitorización de la glicemia capilar en el domicilio, hipoglicemia, complicaciones crónicas, situaciones especiales y apoyo familiar. Los resultados mostraron que fueron incorporados conocimientos relacionados con el concepto, fisiopatología y tratamiento de la enfermedad, actividad física, cuidado con los pies, auto-monitorización, cuidados con la hipoglicemia, complicaciones crónicas y situaciones especiales. Por otra parte, la alimentación y el apoyo familiar necesitan de mayor desenvolvimiento. Se concluye que, después de cinco años del proceso educativo, hubo retención de la mayor parte de los conocimientos brindados.

\author{
DESCRIPTORES \\ Diabetes mellitus \\ Educación en salud \\ Atención Primaria de Salud \\ Enfermería en salud pública
}

DESCRIPTORS

Diabetes mellitus

Primary Health Care

Public health nursing
Educação em saúde

Atenção Primária à Saúde

Enfermagem em saúde pública

1 Undergraduate Nursing student, School of Nursing of Ribeirão Preto, University of São Paulo. Undergraduate research grant funded by the National Council for Scientific and Technological Development (Conselho Nacional de Desenvolvimento Científico e Tecnológico - CNPq). Ribeirão Preto, SP, Brazil. bel_543@hotmail.com ${ }^{2}$ Undergraduate Nursing student, School of Nursing of Ribeirão Preto, University of São Paulo. Undergraduate research grant funded by CNPq. Ribeirão Preto, SP, Brazil. josana.camilo@usp.br ${ }^{3}$ Psychologist. Associated Professor, School of Philosophy, Science, and Languages of Ribeirão Preto, University of São Paulo. Ribeirão Preto, SP, Brazil. masantos@ffclrp.usp.br ${ }^{4}$ Nurse. PhD student, Graduate Fundamental Nursing Program, School of Nursing of Ribeirão Preto, University of São Paulo. Ribeirão Preto, SP, Brazil. flavialuchetti@gmail.com ${ }^{5}$ Nurse. PhD student, Graduate Fundamental Nursing Program, School of Nursing of Ribeirão Preto, University of São Paulo. Ribeirão Preto, SP, Brazil. claarrelias@usp.br ${ }^{6}$ Nurse. Associate Professor, School of Nursing of Ribeirão Preto, University of São Paulo. Ribeirão Preto, SP, Brazil. carlarst@eerp.usp.br ${ }^{7}$ Nurse. Adjunct Professor, Federal University of Amapá. Macapá, AP, Brazil. lumamiyar@hotmail.com ${ }^{8}$ Nurse. Associate Professor, School of Nursing of Ribeirão Preto, University of São Paulo. Ribeirão Preto, SP, Brazil. zanetti@eerp.usp.br 


\section{INTRODUCTION}

Health education is acknowledged to be a crucial component of the treatment of patients with diabetes mellitus (DM). Education affords patients access to tools that are useful for the development of self-care skills and aims at increasing their level of knowledge, improving their ability to manage their disease. The acquisition of such skills is rated as an effective strategy to strengthen their motivation to comply with the dietary plan, increase their physical activity, care for their feet, measure their capillary blood glucose level at home on a regular basis, prevent episodes of hypoglycemia and chronic complications, and manage their disease under special circumstances. In addition, the patients' family must be included as a care unit ${ }^{(1)}$.

Diabetes education is a permanent process that should evolve in a gradual, continuous, interactive, and appropriate manner that takes the students' characteristics into consideration in a wide scope of circumstances and environments by applying individual and/ or group-based strategies of assistance. This process allows for the construction of knowledge that is favorable to self-care, promoting the patients' autonomy in their quest to achieve satisfactory metabolic control and a consequently healthier life ${ }^{(2)}$.

Based on the assumption that diabetes education is an effective strategy to achieve metabolic control, a followup study was conducted over 12 months with patients with DM in a municipality at the interior of the state of São Paulo in 2005 using the protocol Staged Diabetes Management (SDM). The results showed that the educational program contributed to improving the participants' metabolic control and to increasing their knowledge of disease ${ }^{(3)}$. Following the end of the study, the participants were referred back to their original healthcare institutions, with the recommendation to continue their treatment according to the orientation received. However, there is a knowledge gap about the long-term maintenance of the positive results achieved by the program after its end.

There are few Brazilian studies on the long-term maintenance of the positive effects of structured educational programs ${ }^{(4-6)}$. Therefore, the present study sought to assess whether the knowledge acquired during the educational program was maintained five years after its end.

The aims of the present study were to describe the sociodemographic and clinical characteristics of patients with DM and to assess their knowledge on the treatment of disease five years after the end of an edu- cational program. The results are expected to provide sound grounds for understanding the challenges posed to the long-term effectiveness of interventions in DM.

\section{METHOD}

This was a cross-sectional study conducted at a primary care service in a city located in the interior of the state of São Paulo from September to December 2010. The study population comprised the 54 individuals with DM who had participated in the 2005 diabetes education program with a 12-month follow up. The study thus included adults with types 1 and 2 DM who had participated in the 2005 study and agreed to participate in the present study. Fourteen individuals were excluded: ten because their telephone numbers were wrong or the line was reported as out of service, two who had died, one who was hospitalized, and one who traveling. Thus, the final sample comprised 40 volunteers with DM.

The data collection was performed using two instruments elaborated by Otero in 2005. One was a form comprising sociodemographic (gender, age, marital status, educational level, occupational status, and family income) and clinical data (type of DM, time since diagnosis, length of treatment, pharmacological and non-pharmacological treatment, hospital admissions, reported chronic complications and comorbidities, health institution where treatment is performed, random capillary blood glucose, systolic and diastolic arterial pressure, and body mass index - BMI). The other instrument is a form used to collect data on the patient's knowledge of disease and treatment that comprises 34 closed-ended questions distributed along nine sections. The first section is devoted to their general knowledge of the disease, the second to physical activity, the third to nutrition, the fourth to foot care, the fifth to knowledge of clinical parameters, the sixth to knowledge of hypoglycemia, the seventh to knowledge of chronic complications, the eight to special situations, and the ninth to family support. These variables were selected as a function of their relevance for the prevention of chronic and acute complications along the treatment of DM.

For the purpose of data collection, the volunteers were initially contacted by telephone to invite them to participate in the study based on a registration list available at the investigated service. A minimum of three to a maximum of nine telephone calls were made per volunteer. A visit to the service was scheduled for the volunteers who agreed to participate. In the cases where it was difficult or impossible to visit the service, a home visit was scheduled. Thus, 20 volunteers were interviewed at the service (seven at the first meeting, six at
Patients' knowledge of DM five years after the end of an educational program

Chagas IA, Camilo J, Santos MA, Rodrigues FFL, Arrelias CCA, Teixeira CRS, Otero LM, Zanetti ML 
the second, and seven at the last), and 20 volunteers were interviewed at home. Two days before the date scheduled for the interviews, the investigator called the volunteers by telephone to remind them of the appointment.

To address the data collection and aim at its accuracy, the interviews were conducted with a small group of volunteers per visit, up to a total of three visits. The nature, aim and procedures of the study were explained, and the participants who agreed and were available to participate were requested to sign an informed consent form.

Next, the measurement of the volunteers' arterial pressure, body weight, and random capillary blood glucose was performed, which was followed by interviews where the abovementioned instruments were applied. The data collection was performed in a private setting both at the service and home visits and lasted 90 minutes on average.

In the assessment of the arterial pressure, the recommendations for adults with DM by the American Diabetes Association $^{(7)}$ were used, according to which the values must be $130 / 80 \mathrm{mmHg}$. The BMI was assessed based on the values recommended by the World Health Organization $^{(8)}$. The random capillary blood glucose was assessed according to the recommendations of the Brazilian Diabetes Society, according to which the upper level of normal is $140 \mathrm{mg} / \mathrm{dl}^{(9)}$.

To organize the data, a database was generated using the statistical software SPSS (Statistical Package for Social Sciences) for Windows, modules Base and Exact Test version 14.0, where the data were entered twice. The data were expressed as absolute and percent values. In the analysis of the volunteers' responses related to their knowledge of the treatment, the nine sections of the questionnaire were analyzed separately. A score of one (1) was attributed to each correct answer, and thus, the maximum scores for each section were as follows: notion, physiology, and treatment - 28; physical activity - 14 ; nutrition -14 ; foot care -13 ; self-monitoring - 3; hypoglycemia - 20; chronic complications - 8; special situations - 11 ; and family support - 5 , to a global maximum score of 116 .

The absolute values described relative to the patients' knowledge correspond to the sum of the scores of each item. As a result, the maximum scores of each section were as follows: notion, physiology, and treatment - 1,120; physical activity - 560; nutrition - 520; foot care - 520; glucose self-monitoring - 120; hypoglycemia - 800; chronic complications - 320; special situations - 440; and family support - 200.

The study was approved by the research ethics committee of the Nursing School of Ribeirão Preto, University of São Paulo, protocol no. 1151/2010.

\section{RESULTS}

DOf the $40(100 \%)$ volunteers, $32(80.0 \%)$ were female, and the median age of the sample was 66 years old. A total of 24 (60.0\%) volunteers were married or lived with a partner, 19 (47.5) were retired, and 18 (45.0\%) were homemakers. Twenty-five participants had not finished elementary school (62.5\%), and 30 (75\%) had a family income that was equivalent to one to four times the minimum wage, with a median of three times the minimum wage.

Twenty-nine (72.5\%) participants reported having type 2 DM, type 1 was reported by two (5\%), and nine (22.5\%) were not able to report the type of DM they had. The time since the diagnosis of disease varied from 9 to 49 years, being 16 to 20 years in $11(27.5 \%)$ cases. The length of treatment varied from 4 to 40 years.

A total of 22 (55\%) volunteers reported compliance with the dietary plan, while 21 (52.5\%) reported that they did not to adhere to the physical activity program. A total of 29 (72.5\%) participants used oral hypoglycemic drugs, alone in 18 (45\%) cases and combined with insulin in 11 $(27.5 \%)$ cases. The use of insulin alone was reported by seven (17.5\%) participants, while four (10\%) used no medication whatsoever. A total of 36 volunteers (90\%) also continuously used medication against arterial hypertension, dyslipidemia, and other conditions.

In the past five years, 14 (35\%) participants were admitted to hospitals, with an average of 10 days of hospitalization. The most frequent reason for hospitalization was cholecystectomy. Twenty (50\%) volunteers sought assistance at urgent and emergency services, mostly due to episodes of hyperglycemia.

With regard to the chronic complications of DM, retinopathy was reported by nine volunteers (22.5\%), foot problems by nine $(22.5 \%)$, heart problems by nine (22.5\%), neuropathy by eight (20\%), and nephropathy by five $(12.5 \%)$. With regard to comorbidities, 30 (75\%) had arterial hypertension, 23 (57.3\%) were obese, 11 (27.5\%) had dyslipidemia, and 14 (35\%) reported other problems. It is worth noting that $90 \%$ of the sample exhibited at least one chronic complication of their DM.

Seventeen (42.5\%) participants were followed up at Basic Health Units (Unidade Básica de Saúde - UBS), three (7.5\%) at District Basic Health Units (Unidade Básica Distrital de Saúde - UBDS), four (10\%) in the outpatient clinics of a university hospital, fourteen (35\%) at health insurance clinics, and one (5\%) at a private practice, while the disease was not monitored by one (5\%) volunteer.

Based on the BMI, 25 (62.5\%) participants were overweight or obese. Twenty-three (57.5\%) volunteers presented values of their systolic arterial pressure (SAP) that were higher than $130 \mathrm{mmHg}$, and the average was 
$146.7 \mathrm{~mm} \mathrm{Hg}$. The average diastolic arterial pressure (DAP) was $72.5 \mathrm{~mm} \mathrm{Hg}$, it was higher than $80 \mathrm{mmHg}$ in 15 (37.5\%) participants, and it was less than or equal to $80 \mathrm{~mm} \mathrm{Hg}$ in most of the sample (25 individuals, $62.5 \%)$. Twenty-two (55\%) volunteers exhibited a random capillary blood glucose that was higher than 140 $\mathrm{mg} / \mathrm{dl}$ (Table 1).

Table 1 - Distribution of individuals with DM according to BMI, arterial pressure, and glucose level - Ribeirão Preto, SP, Brazil, 2011

\begin{tabular}{llcc}
\hline Variables & Categories & $\mathbf{n}$ & $\mathbf{\%}$ \\
\hline BMI $\left(\mathrm{kg} / \mathrm{m}^{2}\right)$ & $18,5-24,9$ & 4 & 10,0 \\
& $25-29,9$ & 11 & 27,5 \\
& $30-34,9$ & 18 & 45,0 \\
& $35-39,9$ & 4 & 10,0 \\
& $\geq 40$ & 3 & 7,5 \\
\hline Systolic AP & $\leq 130$ & 17 & 42,5 \\
& $>130$ & 23 & 57,5 \\
\hline Diastolic AP $(\mathrm{mmHg})$ & $\leq 80$ & 25 & 62,5 \\
& $>80$ & 15 & 37,5 \\
\hline Capillary glucose $(\mathrm{mg} / \mathrm{dl})$ & $<140$ & 18 & 45,0 \\
& $>140$ & 22 & 55,0 \\
\hline
\end{tabular}

With regard to the participation of the volunteers in other educational programs, only two (5\%) had remained in diabetes educational groups in spite of the positive results achieved.

\section{Participants' knowledge of DM five years after the end of the educational program}

Table 2 describes the number of right answers that were given by the participants to each investigated item: the notion, physiopathology, and treatment of DM; physical activity; nutrition; foot care and examination; hypoglycemia; chronic complications; special situations; and family support. The four sections with the highest number of right answers were the ones related to chronic complications - 246 (76.8\%), foot care - 397 (76.3\%), self-monitoring of capillary blood glucose -87 $(72.5 \%)$, and the notion, physiopathology, and treatment of DM - 807 (72.0\%).

Table 2 - Distribution of the right answers given by the participants according to the investigated disease features - Ribeirão Preto, SP, Brazil, 2011

\begin{tabular}{lcc}
\hline Knowledge of DM-related features & $\mathbf{n}$ & $\mathbf{\%}$ \\
\hline $\begin{array}{l}\text { Diabetes mellitus: notion, } \\
\text { physiopathology and treatment }\end{array}$ & 807 & $72,0 \%$ \\
Hipoglycemia & 526 & $65,7 \%$ \\
Foot care and examination & 397 & $76,3 \%$ \\
Special situations & 312 & $70,9 \%$ \\
Chronic complications & 246 & $76,8 \%$ \\
Nutrition & 205 & $36,6 \%$ \\
Self-monitoring & 87 & $72,5 \%$ \\
Family support & 51 & $25,5 \%$ \\
\hline
\end{tabular}

With regard to the participation of the volunteers in other educational programs, only two (5\%) had remained in diabetes educational groups.

\section{DISCUSSION}

The results of the present study show that the participants exhibited abnormal values of arterial pressure, $\mathrm{BMI}$, and random capillary blood glucose. These findings point to the need for permanent monitoring at primary care services if the benefits achieved by participation in a structured program on diabetes education are to be maintained. From a longitudinal perspective, healthcare services might apply systematized educational strategies that enable the maintenance of the educational program during the course of the treatment, complying with the Unified Health System (Sistema Único de Saúde - SUS).

Regular monitoring allows one to reassess the instituted treatment and to manage the patients' difficulties to comply with the nutritional and exercise plans. In addition, the construction of a glycemic profile contributes to the identification of the attitudes of individuals with DM to acute and chronic complications ${ }^{(10)}$.

The questions on the participants' knowledge of the notion, physiopathology, and treatment of DM exhibited a remarkable percentage of positive answers. These data indicate that the volunteers incorporated the information on the physiopathology and treatment of disease provided by the program they had attended five years earlier. This finding corroborates the results of another study, which demonstrated the relevance of the knowledge acquisition to the prevention of complications, self-care, and maintenance of the metabolic control ${ }^{(11)}$.

The scores relative to the patients' knowledge of physical activity indicate that such an important pillar of non-pharmacological treatment was not theoretically incorporated by the participants as a component of their treatment. There is still a long way to go before physical exercise is effectively adopted, despite the consistent evidence for its beneficial effects on metabolic control in DM, including the improvement of glycemic control, the reduction of the cardiovascular disease risk, the reduction of the body weight, and an increase in self-esteem ${ }^{(12)}$. In this regard, systematic follow up at healthcare units might reinforce the relevance of that domain of knowledge and contribute to the implementation of strategies to stimulate adherence to exercise.

With regard to the participants' knowledge of nutrition, the low scores found agree with the results of other studies ${ }^{(13-14)}$. Despite the low frequency of correct answers, the literature shows that the individuals with DM are aware that compliance with the nutritional plan is an essential component of the treatment, while the mere acquisition of knowledge does not ensure 
adherence $^{(2)}$. Data have shown that compliance with the nutritional plan poses one of the greatest challenges to diabetes education. In this regard, healthcare services ought to acknowledge the relevant role of nutritionists to the orientation of patients with DM relative to their dietary intake, as well as to implementing innovative strategies based on participative methods to stimulate the acquisition of the knowledge needed to manage the nutritional plan.

The answers given by the participants show that they incorporated the knowledge needed to perform the basic care associated with the prevention of diabetic foot. This finding points to an improvement compared to the results of a previous study ${ }^{(15)}$, according to which the individuals with DM were not aware of the actual risks associated with the omission of foot care. The results of the present study show that the participants were able to keep the knowledge acquired on basic care for the prevention of diabetic foot over a long period of time. Additionally, another study found that individuals subjected to an educational program incorporated the knowledge and skills related to foot care ${ }^{(16)}$. These data therefore indicate that the gap between the patients' knowledge and behavior identified by the literature ${ }^{(7)}$ is not insurmountable, but must be faced by healthcare professionals as a challenge that may be overcome through educational programs.

As for the self-monitoring of capillary blood glucose (SMCBG) at home, the level of knowledge of the participants was satisfactory when one keeps in mind that the required equipment was made available at the public healthcare network quite recently. Especially when combined with diabetes education, SMCBG is acknowledged as a relevant educational tool for the adjustment of the nutritional plan, exercise, and pharmacological treatment, as it allows the patients to achieve glycemic control in real time ${ }^{(17)}$.

However, healthcare services must still check systematically whether the patients use the equipment in an appropriate manner and make the means available to help in the interpretation of results at home, aiming at a better management of the disease. Systematic follow up might strengthen the patients' autonomy in self-care, according to the expectations of the healthcare professionals.

Relative to the participants' knowledge on hypoglycemia, the scores show that they mastered its notion, signs and symptoms, and preventive measures. The participants also showed they are aware of the chronic complications of DM, as well as of special situations, such as travel and social events. In contrast, the family support section exhibited the lowest score. Family support is crucial to achieving metabolic control. One study showed that the help and support of relatives are important resources to reinforce the efforts of individuals with DM to comply with their treatment ${ }^{(18)}$. Therefore, healthcare professionals must include the patients' relatives as allies during the follow up of treatment.

The fact that only two participants remained in diabetes educational groups allows us to infer that the patients were generally not encouraged to participate in educational programs or that such programs were not offered by healthcare services. Indeed, individuals with DM should be motivated by their relatives and the healthcare staff to locate the places where such programs are available within municipal healthcare networks.

Diabetes education is considered to provide powerful support for developing an awareness of the relevance of selfcare as a means to prevent the occurrence of complications and improve the quality of life $\mathrm{e}^{(18)}$. The reason for this link is that diabetes education facilitates the patients' acceptance of the disease as well as their understanding of the behavioral changes needed to have an active participation in their own treatment ${ }^{(19)}$.

Acknowledgments by healthcare professionals of the relevance of the patients' knowledge about their disease might increase the efficacy and efficiency of the care provided to individuals with chronic diseases. Such knowledge enables the patients to assimilate the information relevant to their disease so that they might use the primary care services in an appropriate manner.

\section{CONCLUSION}

Analysis of the knowledge of individuals with DM about their disease five years after the end of an educational program showed that the features with the highest percentages of right answers were the ones relevant to chronic complications, foot care, the self-monitoring of capillary blood glucose, and the notion, physiopathology, and treatment of DM. In contrast, the features relevant to nutrition and family support require greater reinforcement.

To summarize, the results of the present study show that in spite of the participation of the volunteers in a systematic diabetes educational program five years earlier, continuous reinforcement of the gains in knowledge is needed for the patients to adopt long-term self-care behaviors. That is to say, the educational process must unfold on a steady basis to ensure the consolidation of the knowledge acquired by the patients.

The present study is clinically relevant because of its originality, the length of the patients' follow up, and the acknowledgment of the relevance of continuous education provided by healthcare professionals at healthcare services. The results showed that a systematic diabetes educational program may have long-standing effects relative to the patients' knowledge of their disease.

The limitations of the present study included the facts that not all of the eligible participants could be recruited and the clinical parameters indicative of metabolic control could not be compared as a function of the characteristics of the study setting, that is, a healthcare service specifically aimed at providing educational support. 


\section{REFERENCES}

1. Landim CAP, Zanetti ML, Santos MA, Andrade TAM, Teixeira CRS. Self-care competence in the case of Brazilian patients with diabetes mellitus in a multiprofessional educational programme. J Clin Nurs. 2011;20(23-24):3394-403.

2. Otero LM, Zanetti ML, Ogrizio MD. Knowledge of diabetic patients about their disease before and after implementing a diabetes education program. Rev Latino Am Enferm. 2008;16(2):231-37.

3. Zanetti ML, Otero LM, Peres DS, Santos MA, Guimarães FPM, Freitas MCF, et al. Progress of the patients with diabetes mellitus who were managed with the staged diabetes management framework. Acta Paul Enferm. 2007;20(3):338-44.

4. Otero LM, Arrelias CCA, Lima YCI, Pena FPS, Santos MA, Teixeira CRS, et al. Seguimento de pacientes com diabetes mellitus em serviço de atenção básica: parâmetros clínicos e laboratoriais. Rev Enferm UERJ. 2010;18(3):423-8.

5. Correr CJ, Pontarolo R, Wiens A, Rossignoli P, Melchiors AC, Radominsk R, et al. Avaliação econômica do seguimento farmacoterapêutico em pacientes com diabetes melito tipo 2 em farmácias comunitárias. Arq Bras Endocrinol Metab. 2009;53(7): 825-33.

6. Malfatti CRM, Assunção NA. Hipertensão arterial e diabetes na Estratégia de Saúde da Família: uma análise da frequência de acompanhamento pelas equipes de Saúde da Família. Ciênc Saúde Coletiva. 2011;16(1 Suppl):1383-88.

7. American Diabetes Association (ADA). Standard of medical care in diabetes - 2011 (Position Statement). Diabetes Care. 2011;34 Suppl 1:S62-9.

8. World Health Organization (WHO). Obesity: preventing and managing the global epidemic. Report on a WHO Consultation. Geneva: WHO; 2000.

9. Sociedade Brasileira de Diabetes (SBD). Diretrizes da Sociedade Brasileira de Diabetes: 2012-2013. São Paulo; 2012.

10. Torres HC, Franco LJ, Stradioto MA, Hortale VA, Schall VT. Evaluation of group and individual strategies in a diabetes education program. Rev Saúde Pública. 2009; 43(2):291-8.
11. Assunção TS, Ursine PGS. Estudo de fatores associados à adesão ao tratamento não farmacológico em portadores de diabetes mellitus assistidos pelo Programa Saúde da Família, Ventosa, Belo Horizonte. Ciênc Saúde Coletiva. 2008;13(2 Suppl):2189-97.

12. Knuth AG, Bielemann RM, Silva SG, Borges TT, Del Luca GF, Kremer MM, et al. Conhecimento de adultos sobre o papel da atividade física na prevenção e tratamento de diabetes e hipertensão: estudo de base populacional no Sul do Brasil. Cad Saúde Pública. 2009;25(3):513-20.

13. Ribas CRP, Santos MA, Zanetti ML. Representações sociais dos alimentos sob a ótica de pessoas com diabetes mellitus. Interam J Psicol. 2011;45(2):255-62.

14. Pontieri FM, Bachion MM. Crenças de pacientes diabéticos acerca da terapia nutricional e sua influência na adesão ao tratamento. Ciênc Saúde Coletiva. 2010; 15(1):151-60.

15. Rocha RM, Zanetti ML, Santos MA. Comportamento e conhecimento: fundamentos para prevenção do pé diabético. Acta Paul Enferm. 2009;22(1):17-23.

16. Martin IS, Beraldo AA, Passeri SM, Freitas MCF, Pace AE. Causas referidas para o desenvolvimento de úlceras em pés de pessoas com diabetes mellitus. Acta Paul Enferm. 2012;25(2):218-24.

17. Veras VS, Araujo MFM, Rodrigues FFL, Santos MA, Damasceno MMC, Zanetti ML. Assessment of metabolic control among patients in a capillary glucose self-monitoring program. Acta Paul Enferm. 2012;25(3):453-58.

18. Baquedano IR, Santos MA, Teixeira CRS, Martins TA, Zanetti ML. Factors related to self-care in diabetes mellitus patients attended at Emergency Service in Mexico. Rev Esc Enferm USP [Internet]. 2010 [cited 2012 Mar 19];44(4):1017-23. Available from: http://www.scielo.br/pdf/reeusp/v44n4/ en_23.pdf

19. Torres HC, Souza ER, Lima MHM, Bodstein RC. Educational intervention for self-care of individuals with diabetes mellitus. Acta Paul Enferm. 2011;24(4):514-9. 